\title{
CARTA DO EDITOR
}

A publicação de artigos cientíícos obedece a vários critérios, que têm como objetivo divulgar com eficiência, precisão e maior alcance possível as informações e idéias ali registradas.

A busca por um padrão normativo universal requer permanente processo de ajuste e aperfeiçoamento. Não

é de uma vez que se estabelece esse padrão com considerável grau de consenso. E, estando estabelecido, cumpre atualizá-lo para acompanhar as bases indexadoras e o processo de recuperação da informação.

Com este número inauguramos mais uma etapa do processo de reformulação editorial e gráfica do Boletim do Museu Paraense Emílio Goeldi, desta vez normatizando o projeto gráfico, que ganha em funcionalidade e clareza.

Equipe editorial 